\title{
Fully implantable hearing device in isolated congenital external ear canal atresia
}

\author{
İzole konjenital dış kulak yolu atrezisinde tamamı implante edilebilen \\ işitme cihazı uygulaması \\ Hakan Tutar', Veysel A. Savaş', Bülent Gündüz'ㄹ, Yıldırım A. Bayazıt ${ }^{1}$ \\ ${ }^{1}$ Department of Otolaryngology, Faculty of Medicine, Gazi University, Ankara, Turkey \\ ${ }^{2}$ Division of Audiology, Department of Otolaryngology, Faculty of Medicine, Gazi University, Ankara, Turkey
}

\begin{abstract}
Aural atresia is the congenital malformation of the ear characterized by partial or complete atresia of the external ear. Our aim is to show the effectiveness of the MET Fully-Implantable Ossicular Stimulator (FIMOS) Carina ${ }^{\circledR}$ in the treatment of hearing loss with auricular atresia. In this case, we experienced The MET Fully-Implantable Ossicular Stimulator (FIMOS) Carina ${ }^{\circledR}$ to the patient who has bilaterally congenital external ear canal atresia for rehabilitation of hearing loss. In postoperative sixth month audiological test the mean functional gain in a four frequency pure-tone average was approximately $39 \mathrm{~dB}$ HL. The capacity of the Carina ${ }^{\circledR}$ MET ossicular stimulator to provide appropriate gain relative to the degree of hearing loss indicates that the device may be a viable treatment for patients with agenesis of external auditory canal and severe malformation of the middle ear.
\end{abstract}

Key words: Carina ${ }^{\circledR}$, external ear canal atresia, hearing loss, fully implantable hearing device.

Aural atresia is the congenital malformation of the ear characterized by partial or complete atresia of the external ear canal, which is generally associated with malformations of the auricula and middle ear. It may be an isolated disorder or a component of a complex syndrome like Pierre Robin, Francesschetti and Goldenhar affecting multiple organs and systems. ${ }^{[1]}$ The incidence of the external auditory canal atresia is one per $8000-10,000$ births ${ }^{[1]}$ and unilateral atresia is seven times more common than bilateral atresia. ${ }^{[2]}$ In most of these patients, they suffer from a conductive hearing loss with an air-bone gap of 50 to $60 \mathrm{~dB} \cdot{ }^{[3]}$ Defective language development as a consequence of hearing loss, congenital

\section{Özet}

Dış kulak yolu atrezisi, dış kulak yolunun kısmi veya tam gelişim defekti ile karakterize bir konjenital malformasyonudur. Çalışmamızdaki amacimız MET Fully-Implantable Ossicular Stimulator (FIMOS) Carina ${ }^{\circledR}$ ile tadavi edilen bilateral aural atrezi olgusunun sonuçlarını tartışmaktır. Bilateral konjenital aural atrezisi olan işitme kayıplı hasta tamamı implante edilebilen MET Fully-Implantable Ossicular Stimulator (FIMOS) Carina ${ }^{\circledR}$ ile tedavi edilmiştir. Hastanın postoperatif 6. ay odyolojik değerlendirilmesinde saf ses odyometrisinde ortalama 39 dB HL kazancı saptanmıştır. Carina ${ }^{\circledR}$ MET kemikcik zincir uyarımı ile yeteri kadar işitme kazancı sağlamış olup, bilateral aural atrezisi olan kişilerde tedavi amaçlı kullanılabilinir.

Anahtar sözcükler: Carina ${ }^{\circledR}$, dış kulak yolu atrezisi, işitme kaybı, tamamı implante edilebilen işitme cihazı. cholesteatoma and especially physicosocial problems due to cosmetic deformity are the main problems of aural atresia. ${ }^{[4]}$

In the treatment of hearing loss with external ear canal atresia, BAHA and osseo-integrated implants are being used in developed countries. The MET Fully-Implantable Ossicular Stimulator (FIMOS) Carina ${ }^{\circledR}$ is a middle ear device that has a difference from the semi implantable devices in that all components of the device are placed under the skin. So this fully implantable middle ear device brings up many advantages such as no visible external components and allowing swimming, sportive activities. ${ }^{[3]}$
Correspondence: Hakan Tutar, MD. Department of Otolaryngology, Faculty of Medicine,

Gazi University, Ankara, Turkey.

e-mail: drhakantutar@yahoo.com

Received: July 24, 2013; Accepted: October 6, 2013; Published online: January 29, 2014
Online available at:

www.jmedupdates.org doi: $10.2399 /$ jmu. 2013003010 QR code: 


\section{Case Report}

A 44-year-old woman suffering bilateral hearing loss applied our department with the complaint of ineffective hearing device. She had been using a conventional bone conduction hearing device on her left ear for 25 years. On physical examination, both auriculas were normal but there was atresia in the external ear canal bilaterally. On computed tomography of the temporal bone, bilateral external ear canals were atresic and bilateral middle and inner ear structures were normal (Fig. 1). The mean preoperative air conduction was $90 \mathrm{~dB}$ in right ear and $95 \mathrm{~dB}$ in the left ear while the mean preoperative bone conduction was $26 \mathrm{~dB}$ and $37.5 \mathrm{~dB}$ on right and left ears respectively. The speech discrimination score was $40 \%$ on right and $24 \%$ on left ear. A control test performed with bone conduction hearing aid yielded $41 \mathrm{~dB}$ functional gain on the right ear. Under general anesthesia we performed the procedure on the right ear with retroauricular incision slightly behind retroauricular sulcus. We performed cortical mastoidectomy and entered into mastoid antrum. We saw the short process and body of incus and head of malleus. The arm of the mounting bracket of the device was modified to perfectly place the device on the incus body. The mounting bracket was then fitted securely to the mastoid cortex using bone screws. The tip of the transducer was fitted on the incus body. The other external components of the device composed of battery, signal processor, magnet, microphone and receiver coil was placed under the temporooccipital skin. After getting optimum fitting results from the device we finalized the surgical procedure (Fig. 2). The perioperative period was uneventful. In postoperative sixth month audiologic evaluation was performed to the patient. Preoperative and postoperative thresholds were shown in Fig. 3. Preoperative and postoperative speech discrimination was $40 \%$; indicating that there was no iatrogenic hearing loss due to surgical trauma. In postoperative sixth month audiological test, the mean free field pure tone thresholds with Carina ${ }^{\circledR}$ was $31 \mathrm{~dB}$ HL (500 $\mathrm{Hz}, 1000 \mathrm{~Hz}, 2000 \mathrm{~Hz}, 4000 \mathrm{~Hz}$ ) while preoperative was 70 dB HL (Fig. 3). There was $39 \mathrm{~dB}$ functional gain in operated ear with Carina ${ }^{\oplus}$. In addition speech discrimination was increased from $40 \%$ to $68 \%$ in the quiet field. Also increased from $28 \%$ to $48 \%$ in the noisy field when the signal/noise ratio was equal to 10 .

\section{Discussion}

In general, otological microsurgery should be considered the main treatment option for conductive hearing loss. Nevertheless, in cases of severe congenital deformities such as aural atresia, surgical treatment proves to be difficult even

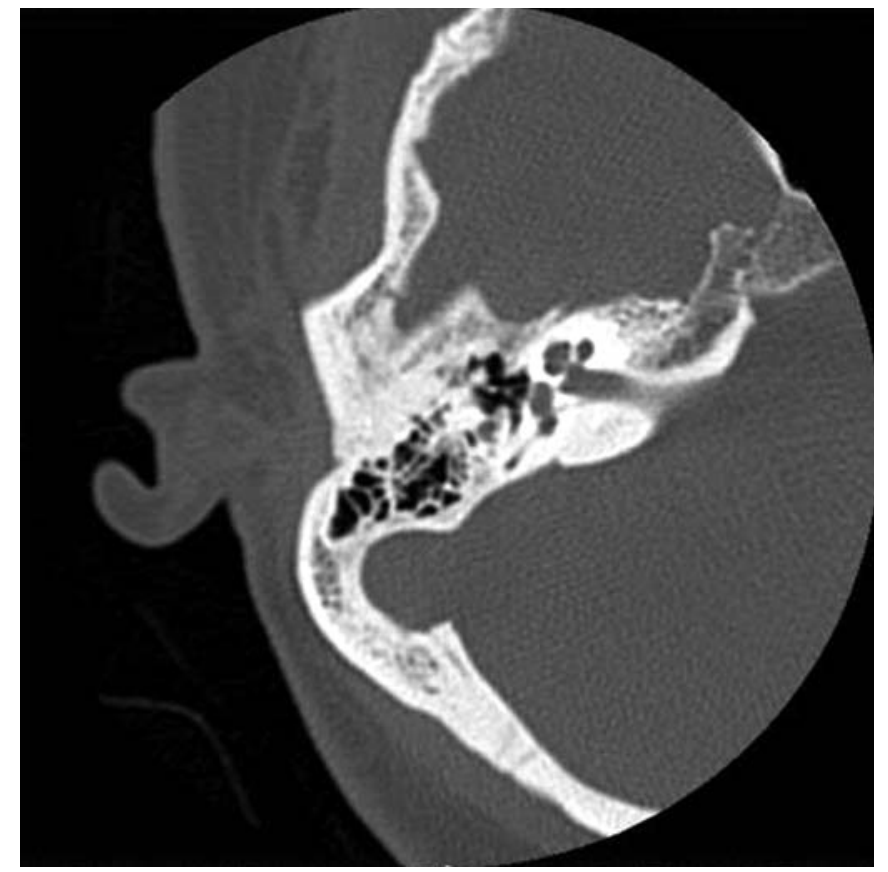

Fig. 1. Preoperative computed tomography view of right ear.

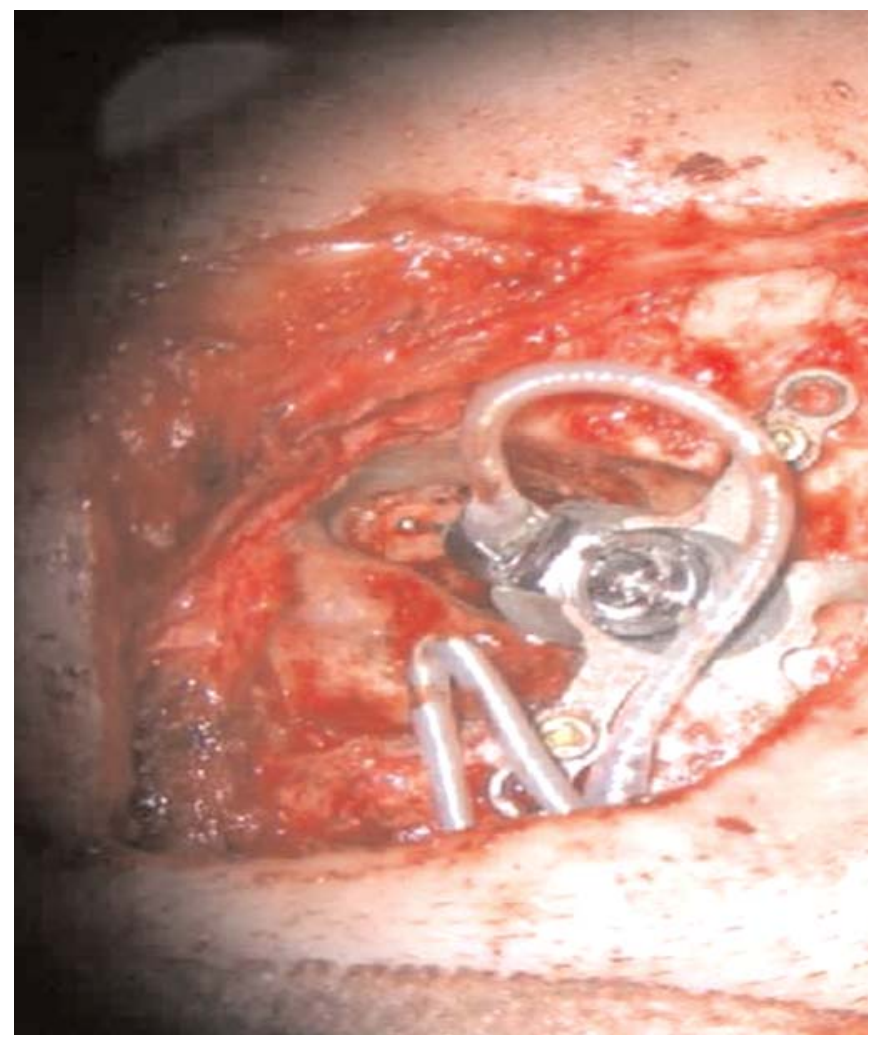

Fig. 2. Intraoperative view of the right ear. The transducer was positioned in the body of incus. 
when performed by the most expert surgeons. ${ }^{[6]}$ Atresiaplasty requires excellent judgment and advanced skills. Atresiaplasty is relatively lengthy and carries a very small risk of facial nerve injury and sensorineural hearing loss. Meatal stenosis and recurrent infection are fairly common. ${ }^{[5]}$ Failure of complete closure of the air-bone gap following atresiaplasty may be corrected with a conventional hearing aid or BAHA.

In fact, in a series of 93 patients with bilateral aural atresia treated with reconstructive surgery (for a total of 100 operated ears) Chang et al ${ }^{[6]}$ reported a mean residual airbone gap of $30 \mathrm{~dB}$ HL; Digoy and Cueva ${ }^{[7]}$ reported a mean residual gap of $23 \mathrm{~dB} H L$, and Declau et al. ${ }^{[8]}$ reported that the auditory threshold after surgical reconstruction was no better than 25-30 dB HL even in the mildest malformations. Cosmetic is generally good for atresiaplasty.

BAHA fixture placement is relatively rapid and simple, but two surgical stages are required for young children with thin skulls. Cosmetic is not ideal with a visible metal abutment and a snap-on hearing aid. Hearing results are usually excellent for BAHA with an expected air-bone gap of only 16-18 dB HL. ${ }^{[9]}$ BAHA complications include occasional loss of the fixture from infection, and fairly common surgical site infections with flap thickening that may require revision surgery. ${ }^{[9]}$ The patient must also be careful to avoid trauma to the BAHA site, which may result in loss.

Until now, treatment modalities for congenital aural atresia were bone-conducting hearing aids, either conventional with a head-band or arc- or bone-anchored with a screw, or a special tympanoplasty, the so-called atresia operation. Carina ${ }^{\circledR}$ is an ossicular stimulator which is the more recent version of the implantable devices. It is used in rehabilitation of moderate to severe sensorineural and mixed type hearing loss. It is also possible to use a fully implantable hearing aid such as Carina ${ }^{\circledR}$ for patients with congenital aural atresia.

This surgical procedure with placement of the tip of transducer to the incus presents no unusual challenge or difficulty, because this procedure is the same as that used for middle-ear implantation of Otologics MET.

Tringali et al. ${ }^{[10]}$ implanted the Carina ${ }^{\circledR}$ in a patient suffering conductive hearing loss due to Franceschetti syndrome. There was bilateral external ear atresia and ossicular malformation. They have placed the implant transducer into the stapedotomy window. Hearing improvement was $29 \mathrm{~dB}$ HL on pure tone audiological evaluation. ${ }^{[10]}$ Siegert et al. ${ }^{[3]}$ implanted Carina ${ }^{\circledR}$ in 5 external ear atresia patients with ossicular malformations. The transducer was connected to

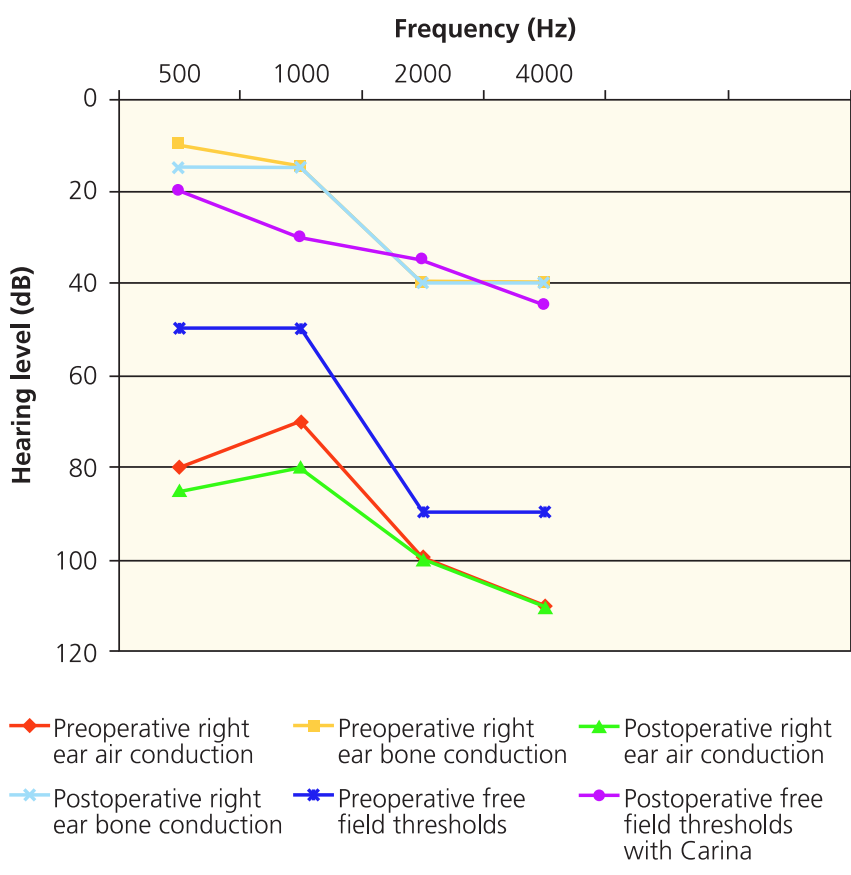

Fig. 3. Preoperative and postoperative audiological evaluation of right ear and free field thresholds.

the malformed malleus-incus complex in two patients similar to the technique used to connect it to the incus in patients with normal middle ears. In three patients they used a special basket prothesis to connect the transducer to stapes. The mean hearing improvement was $35 \mathrm{~dB}$ HL.

In this case we implanted a fully implantable middle ear hearing device Carina ${ }^{\circledR}$ for a patient with hearing loss due to isolated congenital external ear canal atresia. As conclusion the fully implantable active middle ear implant, Carina ${ }^{\circledR}$ could be a new alternative for the rehabilitation of hearing loss in congenital aural atresia with better cosmetic results. Further studies are needed to support our results as well as long term follow-up.

Conflict of Interest: No conflicts declared.

\section{References}

1. Verhagen CV, Hol MK, Coppens-Schellekens W, Snik AF, Cremers CW. The Baha Softband. A new treatment for young children with bilateral congenital aural atresia. Int J Pediatr Otorhinolaryngol 2008;72:1455-9.

2. Jahrsdoerfer RA. Surgery for congenital aural atresia. In: Glasscock ME, Gulya AJ, editors. Glasscock-Shambaugh's surgery of the ear. 5th ed. Hamilton: BC Decker; 2003.

3. Siegert R, Mattheis S, Kasic J. Fully implantable hearing aids in patients with congenital auricular atresia. Laryngoscope 2007;117: $336-40$. 
4. El-Begermy MA, Mansour OI, El-Makhzangy AM, El-Gindy TS. Congenital auditory meatal atresia: a numerical review. Eur Arch Otorhinolaryngol 2009;266:501-6.

5. Teufert KB, De la Cruz A. Advances in congenital aural atresia surgery: effects on outcome. Otolaryngol Head Neck Surg 2004;131: 263-70.

6. Chang SO, Choi BY, Hur DG. Analysis of the long-term hearing results after the surgical repair of aural atresia. Laryngoscope 2006; 116:1835-41.

7. Digoy GP, Cueva RA. Congenital aural atresia: review of shortand long-term surgical results. Otol Neurotol 2007;28:54-60.
8. Declau F, Cremers C, Van de Heyning P. Diagnosis and management strategies in congenital atresia of the external auditory canal. Study Group on Otological Malformations and Hearing Impairment. Br J Audiol 1999;33:313-27.

9. Pfiffner F, Kompis M, Stieger C. Bone-anchored hearing aids: correlation between pure-tone thresholds and outcome in three user groups. Otol Neurotol 2009;30:884-90.

10. Tringali S, Pergola N, Berger P, Dubreuil C. Fully implantable hearing device with transducer on the round window as a treatment of mixed hearing loss. Auris Nasus Larynx 2009;36:353-8.

This is an open access article distributed under the terms of the Creative Commons Attribution-NonCommercial-NoDerivs 3.0 Unported (CC BYNC-ND3.0) Licence (http://creativecommons.org/licenses/by-nc-nd/3.0/) which permits unrestricted noncommercial use, distribution, and reproduction in any medium, provided the original work is properly cited.

Please cite this article as: Tutar H, Savaş VA, Gündüz B, Bayazıt YA. Fully implantable hearing device in isolated congenital external ear canal atresia. J Med Updates 2013;3(3):154-157. 